\title{
PHYSICAL ACTIVITY AND EXERCISE AS A KEY FACTOR IN SUCCESSFUL AGING
}

\author{
Eleonora CAPATTI, Edoardo DALLA NORA, Angelina PASSARO \\ University of Ferrara, Department of Medical Sciences, Section of Internal Medicine and \\ Cardio-Respiratory, Via Aldo Moro ${ }^{\circ} 8$, Cona 44121 Ferrara, Italy \\ Corresponding Author: \\ Angelina PASSARO, MD, PhD. \\ University of Ferrara, Department of Medical Sciences, Section of Internal Medicine and \\ Cardio-Respiratory, Via Aldo Moro n ${ }^{\circ}$, Cona 44121 Ferrara, Italy \\ Tel +0390532 239012 \\ e-mail:psn@unife.it
}

\section{ABSTRACT}

Aging is associated with several changes in body composition and metabolism, including sarcopenia, sarcopenic obesity and decrease in bone mass; aerobic capacity, muscle mass and strength tend to decline progressively. These changes have considerable impact on the ability to perform daily activities, especially when associated with chronic diseases, such as type 2 diabetes, cardio-vascular disease and dyslipidemia, as well as geriatric syndromes, like mobility impairment, falls and frailty. Scientific research has shown that physical activity and exercise can slow the physiological aging clock. Particularly, active elderly people seem to age "successfully" compared to sedentary ones. The aim of our work is to review evidence-based recommendations for physical activity, exercise and diet that would help to preserve muscle mass and strength, and to reduce the gain of fat mass in older adults. Increasing levels of physical activity, in particular resistance training mixed with aerobic exercise, and adequate protein nutrition intake should be an integral component in the prevention and treatment of sarcopenia, sarcopenic obesity and metabolic syndrome in elderly subjects.

Key words: sarcopenia, physical activity, body composition, energy consumption, nutrition, aging. 


\section{GIBALNA AKTIVNOST IN VADBA KOT KLJUČNA FAKTORJA PRI USPEŠNEM STARANJU}

\section{IZVLE $\check{C} E K$}

Staranje je povezano s številnimi spremembami v telesni zgradbi in metabolizmu kot so npr. sarkopenija, sarkopenična debelost in zmanjševanje kostne gostote. Posledično se progresivno zmanjšujejo aerobna kapaciteta ter mišična masa in moč. Te spremembe odločilno vplivajo na sposobnost opravljanja vsakdanjih aktivnosti, še zlasti v povezavi z morebitnimi kroničnimi boleznimi kot so npr. sladkorna bolezen tipa 2, kardio-vaskularne bolezni in dislipidemija pa tudi raznimi geriatričnimi sindromi kot so motnje $v$ gibanju, padci in krhkost. Znanstvene raziskave so pokazale, da gibalna aktivnost in vadba lahko upočasnita fiziološko uro staranja. Predvsem se zdi, da se aktivni starostniki starajo »bolj uspešno«, kot pa sedentarni. Namen članka je pregled priporočil, pridobljenih na osnovi raziskav in dokazov, za gibalno aktivnost, vadbo in prehrano, ki bi pomagali starejšim odraslim ohraniti mišično moč in maso ter hkrati zmanjševati maščobno maso. Povečevanje stopnje gibalne aktivnosti, predvsem vadbe za moč v povezavi z aerobno vadbo, ter ustrezna prehrana bogata s proteini, bi morale biti integralne komponente pri preprečevanju in obravnavi primerov sarkopenije, sarkopenične debelosti ter metaboličnih sindromov pri starejših osebah.

Ključne besede: sarkopenija, gibalna aktivnost, telesna zgradba, poraba energije, prehrana, staranje

\section{INTRODUCTION}

Aging is associated with major changes in body composition, including an increase and redistribution of adipose tissue and a decrease in skeletal muscle mass (sarcopenia) and bone mass, events that begin generally around the fourth decade of life (Fiatarone Singh, 2002).

Recent population trends (Swinburn et al., 2011) indicate an alarming rise in the prevalence of obesity among older adults, potentially adding a complementary condition that compounds the risk of poor health outcomes. The interplay between sarcopenia and rising trends in obesity in aging population emerged more than 20 years ago as an important public health concern in geriatrics (Evans \& Campbell, 1993). The prevalence of sarcopenia and sarcopenic obesity increases with age, thus, muscle mass and strength lead to a progressive decline (Zamboni, Mazzali, Fantin, Rossi, \& Di Francesco, 2008). These changes have considerable impact on the ability of performing daily activities (Batsis, Mackenzie, Lopez-Jimenez, \& Bartels, 2015; Baumgartner et al., 2004) and have also significant consequences in health and functioning of the 
individual, because of their association with chronic disease's expression and severity, as well as with mobility impairment, risk of falls and frailty.

Changes in muscle, fat and bone surely relate to an excess / incorrect energy consumption, decreased energy expenditure in physical activity, or both factors in combination. However, in elderly subjects, other mechanisms are involved, such as changes in hormones regulating metabolism, like growth and sex hormones (Sakuma \& Yamaguchi, 2012).

This declining need for energy due to a reduction in the amount of lean body mass and a more sedentary lifestyle, together with an inappropriate dietary intake, is the first step in the development of malnutrition in the elderly.

The main age-related changes in body composition and physiologic function which appear to influence nutrient requirements in older adults are listed in Table 1 (Blumberg, 1997). Dietary intervention has to be considered a key part of the demographic challenge of an aging population and should be a fundamental part of the public health policy necessary to reduce chronic diseases and compress morbidity (Bendich \& Deck-

Table 1. Examples of Age-Related Changes in Body Composition and Physiologic Function that Influence Nutrient Requirements (modified from Blumberg, 1997).

\begin{tabular}{|l|l|}
\hline $\begin{array}{l}\text { Changes in body composition or } \\
\text { physiological function }\end{array}$ & Impact on nutrient requirements \\
\hline Decreased muscle mass & Decreased need for energy \\
\hline Decreased bone density & Increased need for calcium and vitamin D \\
\hline Decreased immune function & $\begin{array}{l}\text { Increased need for vitamin B6, vitamin E and } \\
\text { zinc }\end{array}$ \\
\hline $\begin{array}{l}\text { Increased gastric pH and decreased gastric } \\
\text { motility }\end{array}$ & $\begin{array}{l}\text { Increased need for vitamin B6, folic acid, } \\
\text { calcium, iron, zinc, fiber and water }\end{array}$ \\
\hline $\begin{array}{l}\text { Decreased skin capacity for cholecalciferol } \\
\text { synthesis }\end{array}$ & Increased need for vitamin D \\
\hline $\begin{array}{l}\text { Increased wintertime parathyroid hormone } \\
\text { production }\end{array}$ & Increased need for vitamin D \\
\hline Decrease calcium bioavailability & Increased need for calcium and vitamin D \\
\hline $\begin{array}{l}\text { Decreased efficiency in metabolic use of } \\
\text { vitamin B6 }\end{array}$ & Increased need for vitamin B \\
\hline $\begin{array}{l}\text { Increased oxidative stress and homocysteine } \\
\text { levels }\end{array}$ & $\begin{array}{l}\text { Increased need for beta-carotene, vitamin C, } \\
\text { vitamin E, folate, vitamin B12 and B6 }\end{array}$ \\
\hline Decreased vitamin absorption & $\begin{array}{l}\text { Increased need for food choices with high } \\
\text { nutrient density }\end{array}$ \\
\hline
\end{tabular}


elbaum, 2015), as well as physical activity and exercise, capable of slowing down the physiological aging clock (Taylor et al., 2004).

\section{METHODS}

Relevant medical literature was identified from searches of PubMed and references cited in appropriate articles identified. Search terms used included sarcopenia, aging, physical activity, elderly, exercise, body composition, aging metabolism, nutrition. More detailed search terms were used following the identification of relevant mechanisms and to identify epidemiological studies. Selection of articles was based on peer review, journal and relevance.

\section{AGE-RELATED CHANGES IN BODY COMPOSITION AND BODY METABOLISM}

Sarcopenia, commonly associated with fat infiltration into muscles (sarcopenic obesity), is very common, with a prevalence of $\sim 5 \%$ in persons aged 65 years and as high as $50 \%$ over the age of 80 (Janssen, 2010). It leads to a decline in muscle strength and power, supported also by altered muscle energetics, changes in tendon insertion, altered muscle coordination and decreased blood flow in the capillary bed of the muscle. Fat infiltration into muscle (myosteatosis) is associated with decreased strength and an increase in the prevalence of disability (Rolland et al., 2009).

As an adequate nutrient intake is essential to maintain muscle mass, the decline in food intake with aging plays a role in the development of sarcopenia. In particular, maintenance of muscle mass requires adequate protein intake; it is postulated that older persons require at least $1.2 \mathrm{~g} / \mathrm{kg}$ of protein a day (Morley et al., 2010).

From a metabolic point of view, the most important consequence of sarcopenia is the decrease in energy expenditure (in particular for physical activity) and basal metabolic decline; moreover, the ability to increase or decrease energy expenditure to counterbalance overeating or undereating is impaired with an increased susceptibility to energy imbalance (both positive and negative) (Roberts \& Rosenberg, 2006). A decline in basal metabolic rate (BMR) with aging is well recognized (Poehlman, 1992), associated to a loss of fat free mass (FFM) and a gain of fat (FM), a less metabolically active tissue.

A longitudinal study by Keys, Taylor, and Grande (1973) documented a decline in BMR with age of $1-2 \%$ per decade. Other studies examining the role of aging on resting metabolic rate (RMR) and substrate oxidation (Frisard et al., 2007; Krems, Lührmann, Straßburg, Hartmann, \& Neuhäuser-Berthold, 2005) indicate a reduction in RMR with age greater than what would be predicted from the observed modification of FM and FFM, suggesting that the lower RMR of older adults may be due in part to slowed organ metabolic rates (St-Onge \& Gallagher, 2010). 
The lowering of FFM and the increase of FM, in particular of visceral adipose tissue (VAT), is related to an increased risk of cardiovascular disease, type 2 diabetes, hyperlipidemia, hypertension and malignancy (Donohoe, Doyle, \& Reynolds, 2011).

The association of central adiposity to poor health is related to VAT accumulation and associated with hyperinsulinemia and insulin resistance. VAT secretes a number of adipokines and inflammatory cytokines (TNF- $\alpha$, IL-6, IL-1 $\beta$ ) that can up-regulate nuclear factor- $\kappa \mathrm{B}(\mathrm{NF \kappa B})$, which leads to an increase in nitric oxide (NO), a substrate for reactive oxygen species (ROS) (Sonnenberg, Krakower, \& Kissebah, 2004).

Moreover, excess adiposity is associated with a state of low-grade chronic inflammation, which interfere with adipose cell differentiation and adipokines pattern secretion, resulting in dysfunctional adipose tissue (Paniagua, 2016). Increased VAT is associated with elevated free fatty acids, impaired hepatic insulin clearance, resulting in hyperinsulinemia, increased gluconeogenesis, and elevation of very-low-density lipoprotein secretion (Matsuzawa et al., 1995).

In this state the subject presents a pro-inflammatory, pro-coagulant and insulin resistant state typical of the metabolic syndrome (Despres \& Lemieux, 2006).

\section{PHYSICAL ACTIVITY AND AEROBIC / ANAEROBIC EXERCISE}

Regular physical activity is one of the most important protective factors against the development of chronic diseases (Harridge \& Lazarus, 2017): sedentary individuals show an higher incidence of cardiovascular disease, diabetes mellitus, obesity as well as different malignancy. On the contrary, physical activity is inversely related to allcause mortality in older adults (Brown et al., 2012).

Besides being active or un-active, also the total amount and intensity of physical activity is important. The physiologic adaptations to aerobic and resistance exercise are different: aerobic exercise improves cardiovascular function, that increase peak oxygen consumption without significantly changing strength, whereas resistance exercise improves neuromuscular adaptations, leading to an increase in strength, without significantly changing peak oxygen consumption. Despite lower baseline values, the available data suggest that older individuals have the same relative improvement in maximal strength and maximal aerobic capacity to resistance training and aerobic training regimens, respectively (Lambert \& Evans, 2005). These physiologic adaptations may integrate with each other when the two types of training are performed together (Wilson et al., 2012). In a recent clinical trial (Villareal et al., 2017), the effectiveness of aerobic exercise has been compared with resistance exercise and combined exercise in reversing frailty and preserving muscle and bone mass, during weight loss in obese older adults. The authors show that combined aerobic and resistance training seems to provide the greatest benefits with respect to physical function (PF) and relative preservation of lean mass. In particular, the most effective exercise protocol for frail older adults seem to be a multi-component training, performed three times per week, with shorter-duration sessions ( $30-45 \mathrm{~min})$, in order to prevent adverse health consequences (Theou et al., 2011). 


\section{PHYSICAL EXERCISE AND CHANGES IN BODY COMPOSITION}

Human body is composed of water, protein, minerals, and fat. The total amount of body fat consists of essential fat (detectable in bone marrow, heart, lungs, liver, spleen, kidneys, muscles, and central nervous system) and storage fat, that accumulates in adipose tissue. Lean body mass (LBM), comprehensive of muscles, bones, ligaments, tendons, and internal organs, differences from FFM for the content of a small percentage of essential fat (bone marrow and organs).

Regular physical activity has an overall positive effect on body composition, modifying both FFM and FM, muscle volume, muscle strength, and physical mobility in older people, including overweight and obese individuals (Liao et al., 2017). Many studies describe a non-significant change, reliable to exercise, in FFM (Toth, Beckett, \& Poehlman, 1999), even if exercise leads to an increase in skeletal muscle mass, especially if anaerobic one, with a related increase in strength.

According to different studies on elderly people, an aerobic exercise of moderate intensity $\left(\mathrm{VO}_{2 \max }>60 \%\right)$, is generally associated to a lowering in total body fat (FM), even in the absence of changes in dietary regime, proportional to the amount of training sessions. In particular, aerobic exercise can induce significant results on the loss of adipose tissue in the abdominal region (VAT) (Kay \& Fiatarone Singh, 2006).

In order to estimate $\mathrm{VO}_{2 \max }$ and fitness index, a two-km walking test was developed by the UKK Institute in Finland (Laukkanen, Oja, Ojala, Pasanen, \& Vuori, 1992). This test, relatively simple to administer, is a feasible and accurate alternative for determination of cardio-respiratory fitness in adults with both normal body weight as well as in overweight individuals. In Ferrara's population of PANGeA study (a mass population study we conducted with Slovenian colleagues, aiming at identifying the main elements involved in successful aging), applying the UKK-test, we found that fitness index is inversely correlated to waist circumference. In this population, applying a linear regression model, fitness index, independently of gender and age, predicts waist circumference, explaining the $32 \%$ of its variability $\left(\mathrm{R}^{2}\right.$ square 0,322 , standardized $\beta$-coefficient $-0,477, \mathrm{p}<0,001$ ) (Figure 1, data not published).

\section{PHYSICAL EXERCISE AND CHANGES IN BODY METABOLISM}

Even if not associated with a specific dietary regime, aerobic exercise and resistance training may be responsible for different and positive changes in body metabolism:

- improvement in glycemic control (Sigal et al., 2007), due to increases in muscle GLUT4 number and function (Holten et al., 2004),

- improvements in insulin sensitivity (Winnick et al., 2008),

- stimulation of lipid oxidation,

- improvement in lipid profile with increased clearance of atherogenic lipids, specially triglycerides (Katsanos, 2006), reduced levels of total cholesterol and apolipoprotein B (Holme, Høstmark, \& Anderssen, 2007), changes in LDL par- 


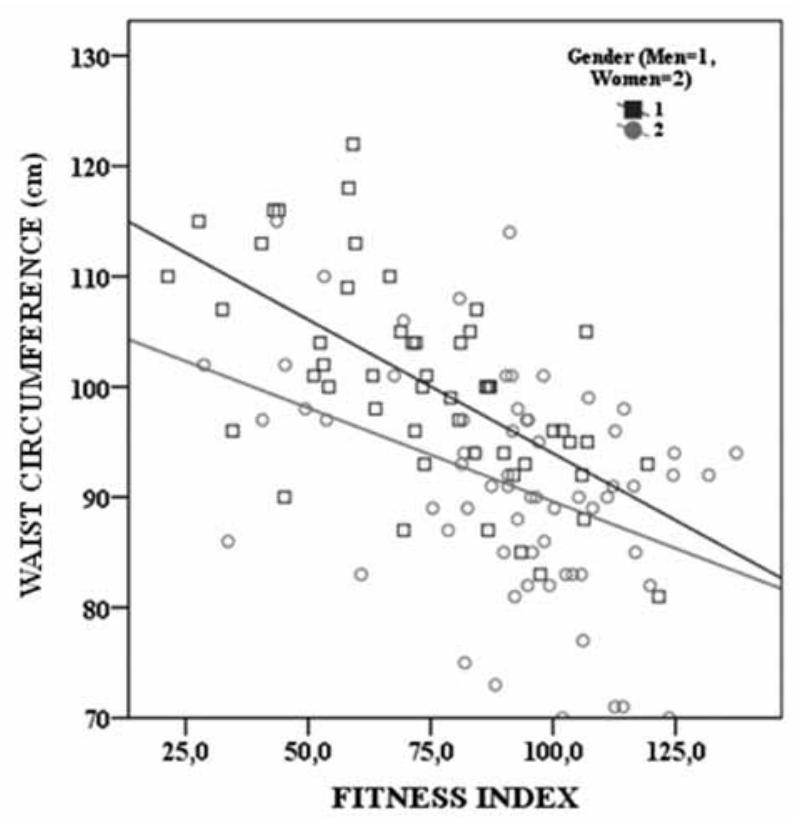

Figure 1. Pearson correlation between fitness index and waist circumference (PANGeA's Ferrara population): Men $r=-0,62, p<0.001$; Women $r=-0,401, p=0,001$.

ticle size (more than lower levels) and higher HDL concentration (Kraus et al., 2002),

- decrease of VAT in relation to an increased sympathetic tonus and consequential increased lipolysis (Ismail, Keating, Baker, \& Johnson, 2012),

- decrease of VAT and pro-inflammatory state may contribute to improve glucose uptake (Fisher et al., 2011),

- decrease in biomarkers of inflammation like C-reactive protein (CRP) (Strasser, Arvandi, \& Siebert, 2012),

- improvement in adiponectin and leptin profile (Simpson \& Singh, 2008).

The impact of aerobic exercise on body metabolism is better and more significant if it is characterized by high intensity; strength training can provide up to a $15 \%$ increase in metabolic rate, which is very helpful in terms of weight loss and long-term weight control.

A review published by Strasser provides strong support for the recommendation that physical activity, in particular resistance training mixed with aerobic exercise, should be an integral component in the prevention and treatment of obesity and metabolic syndrome risk factors (Strasser, 2013). Resistance training is an effective way to increase energy requirements, decrease body FM, and maintain metabolically active 
tissue mass. A consequent improvement in insulin sensitivity and in the lipid profile could reduce the risk of metabolic syndrome and type 2 diabetes and attenuate the development of cardiovascular disease in an elderly population (Ferrara, Goldberg, Ortmeyer, \& Ryan, 2006).

\section{PHYSICAL ACTIVITY AND RELATED BENEFITS}

It is well established that with increasing age, individuals are more likely to experience functional declines, mobility limitations, and physical disability (Holmes, PowellGriner, Lethbridge-Cejku, \& Heyman, 2009). A large body of literature has supported the interrelationships among various factors affecting physical function (PF) in older adults (Villareal et al., 2011), like physical activity, body composition (fat mass and skeletal muscle mass), muscle capacity (leg strength and leg power), and muscle quality, whose aging-related changes tend to promote a decline in maximal aerobic power and skeletal muscle force production. Although the likelihood of physical limitations and disability increases with age, multiple studies have demonstrated that exercise is an effective intervention strategy for improving PF in older adults (Brady, Straight, \& Evans, 2014).

Several intervention trials have reported improvements in PF after a resistance training program in relatively healthy older (Avila, Gutierres, Sheehy, Lofgren, \& Delmonico, 2010; Henwood \& Taaffe, 2005), as well as older adults with chronic health conditions (Yang, Wang, Lin, Chu, \& Chan, 2006). In addition, aerobic training, often a cornerstone of an exercise program, has also been found to be beneficial at improving PF in older adults (Davidson et al., 2009).

The evidence suggests how the pillars of an effective exercise program should be both aerobic and resistance exercise (Chodzko-Zajko et al., 2009) and it is well known that both endurance exercise and resistance training can substantially improve physical fitness and health-related factors in older individuals (Conceição et al., 2014). This helps to maintain and increase skeletal muscle mass and respiratory fitness, with increase in resting metabolic rate and enhanced capacity for lipid oxidation during rest and exercise. Endurance training in particular is purported to be more effective for decreasing FM, resting heart rate and blood pressure, while resistance training has been shown to be more effective for increasing basal metabolism, bone mineral density (BMD) and muscle strength and power (Romero-Arenas, Martínez-Pascual, et al. 2013).

Regular physical activity can have a positive effect on disorders and diseases that affect muscles and bones (such as osteoarthritis, back pain and osteoporosis). Walking provides a modest increase in the loads on the skeleton above gravity and, therefore, this type of exercise has proved to be less effective in osteoporosis prevention. Strength exercises instead, seems to be a powerful stimulus to improve and maintain bone mass during the aging process (Gomez-Cabello, Ara, González-Agüero, Casajús, \& VicenteRodríguez, 2012). 
Many evidences show that physical activity programs aimed at strengthening muscles help the elderly to maintain balance, which decrease the likelihood and severity of falls and fractures, one of major health concerns for many older adults (Howe, Rochester, Neil, Skelton, \& Ballinger, 2011).

Compared to sedentary people, older athletes enjoy a wide range of physiological benefits on health:

- a better profile in body composition including a lower accumulation of total and especially abdominal fat; greater volume muscle mass in upper and lower limbs,

- higher bone mineral density (BMD), especially in case of strength training with high-load low repetitions (Romero-Arenas, Blazevich, et al., 2013),

- articulation muscle more resistant to oxidative processes and fatigue,

- a better cardiac output during maximum exercise and improved cardiovascular fitness (Gibala, Little, MacDonald, \& Hawley, 2012),

- less cardiovascular and metabolic stress during sub-maximal exercise (Lanza et al., 2008),

- significantly reduced coronary risk profile in relation to lowering of blood pressure (Whelton, Chin, Xin, \& He, 2002), improvement in endothelium function (Maiorana, O'Driscoll, Taylor, \& Green, 2003); low systemic inflammatory index; improved insulin sensitivity and glucose homeostasis; better lipid profile and lower waist circumference,

- slowed development of disability in old age.

Twenty to forty minutes a day of aerobic training leads to a lower probability to develop metabolic and cardiovascular diseases. Moreover, several studies have shown the beneficial effects of circuit weight training in individuals with CHD. Volaklis et al. combined resistance circuit and aerobic exercise program in patients with coronary artery disease. Subjects improved cardiovascular fitness $\left(\mathrm{VO}_{2}\right.$ peak $\left.15.4 \%\right)$ and muscular strength significantly in all exercises by an average of $28 \%$ (Volaklis, Douda, Kokkinos, \& Tokmakidis, 2006).

A Cochrane review of 121 randomized controlled trials of progressive resistance training (PRT) in older people showed that doing PRT 2-3 times per week improved physical function, gait speed, timed get-up-and-go, climbing stairs, and balance, and, more importantly, had a significant effect on muscle strength, especially in the highintensity training groups (Crocker et al., 2013).

In order to optimize body composition, muscle strength gains and to develop cardiovascular function, Romero-Arenas, Martínez-Pascual, et al. (2013) recommended a circuit weight training with a minimum frequency of 2 sessions per week (with a volume ranging from 30 to 50 minutes) that could be implemented with endurance training. 


\section{DIET COMBINED WITH PHYSICAL ACTIVITY AND BODY COMPOSITION}

Aging is related with the loss of skeletal muscle and bone mass along with progressive increase of adipose tissue. Recent investigations have attempted to modify these processes with various combinations of dietary and exercise intervention (Iglay, Thyfault, Apolzan, \& Campbell, 2007; Kukuljan, Nowson, Sanders, \& Daly, 2009).

Increasing the quantity and quality (essential amino acids, specifically leucine) of dietary protein stimulates muscle protein synthesis in the elderly (Børsheim et al., 2008), while protein supplementation at twice the Recommended Dietary Allowance (RDA) does not improve skeletal muscle function or increase muscle mass in healthy elderly weight lifters compared to those on a normal diet (Campbell \& Leidy, 2007). Therefore, regular resistance exercises and the habitual ingestion of adequate amounts of dietary protein from high-quality sources are two important ways to slow the progression and treat sarcopenia. Assuming three meals are consumed each day, a relative protein dose of $0.4-0.5 \mathrm{~g} / \mathrm{kg} /$ meal is consistent with recent expert opinions concerning the optimal daily protein intake $(1.2-1.5 \mathrm{~g} / \mathrm{kg} /$ day $)$ for healthy older adults (Deutz et al., 2014).

This amount of protein markedly exceeds the RDA for protein (at present set at 0.8 $\mathrm{g} / \mathrm{kg}$ ideal body mass / day for healthy adults, regardless of sex and age), but it is supported by several larger-scale longitudinal studies (Bartali et al., 2012; Gray-Donald et al., 2014). Several studies have also reported a positive relationship between protein intake and peak bone mass in older adults (Hannan et al., 2000; Sahni et al., 2014).

Increased intake of vitamin D stimulates gene expression and boosts muscle protein synthesis, facilitates neuromuscular function and enhances strength and balance (Muir \& Montero-Odasso, 2011). In a recent clinical trial, Rondanelli et al. found a significant beneficial effect of supplementation with whey protein, essential amino acids, and vitamin D compared with placebo in elderly sarcopenic adults participating in controlled resistance training, with a gain of $1.7 \mathrm{~kg}$ in FFM. Supplementation attenuated the inflammatory state, as seen by the significant drops in CRP concentrations and leads to a reduced prevalence of malnutrition, assessed with the Mini Nutritional Assessment (MNA) (Rondanelli et al., 2016).

In all individuals older than 70 years of age, vitamin D intakes of at least $600 \mathrm{IU}$ per day (up to $1000 \mathrm{IU} /$ day) are recommended, in addition to the calcium requirement of $1200 \mathrm{mg}$ per day (American Geriatrics Society Workgroup on Vitamin D Supplementation for Older Adults, 2014). For those individuals in whom there is inadequate calcium and vitamin D intake from diet, supplements and/or multivitamins can be used.

A recent review suggests that calcium and vitamin D supplementation, with or without osteoporosis therapy, may decrease the risk of fractures (Tricco et al., 2017). Anyway, the U.S. Preventive Services Task Force (USPSTF) concluded that the current evidence is insufficient to assess the balance of benefits and harms of combined vitamin $\mathrm{D}$ and calcium supplementation to prevent bone fractures in premenopausal women or in men (Moyer \& U.S. Preventive Services Task Force*, 2013). 


\section{CONCLUSIONS}

An inevitable consequence of advancing age is the gradual loss of muscle mass and strength, termed sarcopenia, frequently associated with a parallel increase in fat mass. This geriatric condition has known negative impacts on metabolic health, and in later life, the ability to perform everyday activities (Witard, McGlory, Hamilton, \& Phillips, 2016).

This review highlights the major benefits of physical activity in the elderly in terms of body composition and metabolism. Active elderly subjects show a slower "aging clock" and a lighter burden of chronic morbidity. Aerobic exercises help to raise heart and lung efficiency and to increase cardiovascular fitness and endurance, while resistance training promotes an increase in muscle mass and bone density. Achieving these goals represents the first step of a realistic strategy for maintaining functional status and independence.

International guideline recommendations suggest that older people should perform at least 150 minutes of moderate physical activity per week and should be less sedentary in order to achieve health benefits (World Health Organization, 2010). Active elderly in particular, seems to develop a "successful aging" compared to sedentary ones.

Developing simple lifestyle interventions and safe, effective and sustainable ways to promote physical activity, aimed to preserve muscle mass and strength with advancing age, is crucial for the care of patients in mid-life and beyond.

\section{REFERENCES}

American Geriatrics Society Workgroup on Vitamin D Supplementation for Older Adults (2014). Recommendations abstracted from the American Geriatrics Society Consensus Statement on Vitamin D for prevention of falls and their consequences. Journal of the American Geriatrics Society, 62(1), 147-152. doi: 10.1111/jgs.12631 VIEW ITEM

Avila, J. J., Gutierres, J. A., Sheehy, M. E., Lofgren, I. E., \& Delmonico, M. J. (2010). Effect of moderate intensity resistance training during weight loss on body composition and physical performance in overweight older adults. European Journal of Applied Physiology, 109(3), 517-525. doi: 10.1007/s00421-010-1387-9 VIEW ITEM

Bartali, B., Frongillo, E. A., Stipanuk, M. H., Bandinelli, S., Salvini, S., Palli, D., Morais, J. A., et al. (2012). Protein intake and muscle strength in older persons: Does inflammation matter? Journal of the American Geriatrics Society, 60(3), 480-484. doi: 10.1111/j.1532-5415.2011.03833.x VIEW ITEM

Batsis, J. A., Mackenzie, T. A., Lopez-Jimenez, F., \& Bartels, S. J. (2015). Sarcopenia, sarcopenic obesity, and functional impairments in older adults: National Health and Nutrition Examination Surveys 1999-2004. Nutrition Research, 35(12), 1031-1039. doi: 10.1016/j.nutres.2015.09.003 VIEW ITEM 
Baumgartner, R. N., Wayne, S. J., Waters, D. L., Janssen, I., Gallagher, D., \& Morley, J. E. (2004). Sarcopenic obesity predicts instrumental activities of daily living disability in the elderly. Obesity, 12(12), 1995-2004. doi: 10.1038/oby.2004.250 VIEW ITEM

Bendich, A., \& Deckelbaum, R. J. (2015). Preventive nutrition: the comprehensive guide for health professionals $\left(5^{\text {th }}\right.$ ed.). Humana Press.

Blumberg, J. (1997). Nutritional needs of seniors. Journal of the American College of Nutrition, 16(6), 517-523. doi: 10.1080/07315724.1997.10718714 VIEW ITEM

Børsheim, E., Bui, Q.-U. U. T., Tissier, S., Kobayashi, H., Ferrando, A. A., Wolfe, R. R. (2008). Effect of amino acid supplementation on muscle mass, strength and physical function in elderly. Clinical nutrition, 27(2), 189-195. doi: 10.1016/j.clnu.2008.01.001 VIEW ITEM

Brady, A. O., Straight, C. R., \& Evans, E. M. (2014). Body composition, muscle capacity, and physical function in older adults: An integrated conceptual model. Journal of Aging and Physical Activity, 22(3), 441-452. doi: 10.1123/JAPA.2013-0009 VIEW ITEM

Brown, W. J., McLaughlin, D., Leung, J., McCaul, K. A., Flicker, L., Almeida, O. P., Hankey, G. J., et al. (2012). Physical activity and all-cause mortality in older women and men. British Journal of Sports Medicine, 46(9), 664-668. doi: 10.1136/bjsports-2011-090529 VIEW ITEM

Campbell, W. W., \& Leidy, H. J. (2007). Dietary protein and resistance training effects on muscle and body composition in older persons. Journal of the American College of Nutrition, 26(6), 696S-703S. doi: 10.1080/07315724.2007.10719650 VIEW ITEM

Chodzko-Zajko, W. J., Proctor D. N., Fiatarone Singh, M. A., Minson, C. T., Nigg, C. R., Salem, G. J., \& Skinner, J. S. (2009). Exercise and physical activity for older adults. Medicine \& Science in Sports \& Exercise, 41(7), 1510-1530. doi: 10.1249/ MSS.0b013e3181a0c95c VIEW ITEM

Conceição, M., Cadore, E. L., González-Izal, M., Izquierdo, M., Liedtke, G. V., Wilhelm, E. N., Pinto, R. S., et al. (2014). Strength Training Prior to Endurance Exercise: Impact on the Neuromuscular System, Endurance Performance and Cardiorespiratory Responses. Journal of Human Kinetics, 44(1), 171-181. doi: 10.2478/hukin-2014-0123 VIEW ITEM

Crocker, T., Forster, A., Young, J., Brown, L., Ozer, S., Smith, J., Green, J., et al. (2013). Physical rehabilitation for older people in long-term care. Cochrane database of systematic reviews, 2, art.no. CD004294. doi: 10.1002/14651858.CD004294.pub3 VIEW ITEM

Davidson, L. E., Hudson, R., Kilpatrick, K., Kuk, J. L., McMillan, K., Janiszewski, P. M., ... Ross, R. (2009). Effects of exercise modality on insulin resistance and functional limitation in older adults: a randomized controlled trial. Archives of internal medicine, 169(2), 122-131. doi: 10.1001/archinternmed.2008.558 VIEW ITEM

Despres, J. P., \& Lemieux, I. (2006). Abdominal obesity and metabolic syndrome. Nature, 444(7121), 881-887. doi:10.1038/nature05488 VIEW ITEM

Deutz, N. E. P., Bauer, J. M., Barazzoni, R., Biolo, G., Boirie, Y., Bosy-Westphal, A., ... Calder, P. (2014). Protein intake and exercise for optimal muscle function with aging: Recommendations from the ESPEN Expert Group. Clinical Nutrition, 33(6), 929-936. doi: 10.1016/j.clnu.2014.04.007 VIEW ITEM

Donohoe, C. L., Doyle, S. L., \& Reynolds, J. V. (2011). Visceral adiposity, insulin resistance and cancer risk. Diabetology \& Metabolic Syndrome, 3(12), 1-13. doi: 10.1186/17585996-3-12 VIEW ITEM 
Evans, W. J., \& Campbell, W. W. (1993). Sarcopenia and age-related changes in body composition and functional capacity. The Journal of nutrition, 123(2 Suppl), 465-468. VIEW ITEM

Ferrara, C. M., Goldberg, A. P., Ortmeyer, H. K., \& Ryan, A. S. (2006). Effects of aerobic and resistive exercise training on glucose disposal and skeletal muscle metabolism in older men. The journals of gerontology. Series A: Biological Sciences and Medical Sciences, 61(5), 480-487. doi: 10.1093/gerona/61.5.480 VIEW ITEM

Fiatarone Singh, M. A. (2002). Benefits of exercise and dietary measures to optimize shifts in body composition with age. Asia Pacific journal of clinical nutrition, 11(3), S642S652. doi: 10.1046/j.1440-6047.11.supp3.17.x VIEW ITEM

Fisher, G., Hyatt, T. C., Hunter, G. R., Oster, R. A., Desmond, R. A., \& Gower, B. A. (2011). Effect of diet with and without exercise training on markers of inflammation and fat distribution in overweight women. Obesity (Silver Spring, Md.), 19(6), 1131-1136. doi: 10.1038/oby.2010.310 VIEW ITEM

Frisard, M. I., Broussard, A., Davies, S. S., Roberts, L. J., Rood, J., Jonge, L. de, ... Ravussin, E. (2007). Aging, resting metabolic rate, and oxidative damage: Results from the Louisiana healthy aging study. The Journals of Gerontology Series A: Biological Sciences and Medical Sciences, 62(7), 752-759. doi: 10.1093/gerona/62.7.752 VIEW ITEM

Gibala, M. J., Little, J. P., MacDonald, M. J., \& Hawley, J. A. (2012). Physiological adaptations to low-volume, high-intensity interval training in health and disease. The Journal of Physiology, 590(5), 1077-1084. doi: 10.1113/jphysiol.2011.224725 VIEW ITEM

Gomez-Cabello, A., Ara, I., González-Agüero, A., Casajús, J. A., \& Vicente-Rodríguez, G. (2012). Effects of training on bone mass in older adults. Sports Medicine, 42(4), 301-325. doi:10.2165/11597670-000000000-00000 VIEW ITEM

Gray-Donald, K., Arnaud-McKenzie, D. S.-, Gaudreau, P., Morais, J. A., Shatenstein, B., \& Payette, H. (2014). Protein intake protects against weight loss in healthy community-dwelling older adults. Journal of Nutrition, 144(3), 321-326. doi: 10.3945/ jn.113.184705 VIEW ITEM

Hannan, M. T., Tucker, K. L., Dawson-Hughes, B., Cupples, L. A., Felson, D. T., \& Kiel, D. P. (2000). Effect of dietary protein on bone loss in elderly men and women: the Framingham Osteoporosis Study. Journal of Bone and Mineral Research, 15(12), 2504-2512. doi: 10.1359/jbmr.2000.15.12.2504 VIEW ITEM

Harridge, S. D. R., \& Lazarus, N. R. (2017). Physical activity, aging, and physiological function. Physiology, 32(2), 152-161. doi: 10.1152/physiol.00029.2016 VIEW ITEM

Henwood, T. R., \& Taaffe, D. R. (2005). Improved physical performance in older adults undertaking a short-term programme of high-velocity resistance training. Gerontology, 51(2), 108-115. doi: 10.1159/000082195 VIEW ITEM

Holme, I., Høstmark, A. T., \& Anderssen, S. A. (2007). ApoB but not LDL-cholesterol is reduced by exercise training in overweight healthy men. Results from the 1-year randomized Oslo Diet and Exercise Study. Journal of Internal Medicine, 262(2), 235-243. doi: 10.1111/j.1365-2796.2007.01806.x VIEW ITEM

Holmes, J., Powell-Griner, E., Lethbridge-Cejku, M., \& Heyman, K. (2009). Aging differently:physical limitations among adults aged 50 years and over: United States, 2001-2007. National Center for Health Statistics Data Brief, (20), 1-8. Retrieved from https://www.cdc.gov/nchs/products/databriefs/db20.htm 
Holten, M. K., Zacho, M., Gaster, M., Juel, C., Wojtaszewski, J. F. P., \& Dela, F. (2004). Strength training increases insulin-mediated glucose uptake, GLUT4 content, and insulin signaling in skeletal muscle in patients with type 2 diabetes. Diabetes, 53(2), 294 305. doi: 10.2337/diabetes.53.2.294 VIEW ITEM

Howe, T. E., Rochester, L., Neil, F., Skelton, D. A., \& Ballinger, C. (2011). Exercise for improving balance in older people. Cochrane Database of Systematic Reviews, (11), art. no. CD004963. doi: 10.1002/14651858.CD004963.pub3 VIEW ITEM

Iglay, H. B., Thyfault, J. P., Apolzan, J. W., \& Campbell, W. W. (2007). Resistance training and dietary protein: effects on glucose tolerance and contents of skeletal muscle insulin signaling proteins in older persons. The American journal of clinical nutrition, 85(4), 1005-1013. VIEW ITEM

Ismail, I., Keating, S. E., Baker, M. K., \& Johnson, N. A. (2012). A systematic review and meta-analysis of the effect of aerobic vs. resistance exercise training on visceral fat. Obesity Reviews, 13(1), 68-91. doi: 10.1111/j.1467-789X.2011.00931.x VIEW ITEM

Janssen, I. (2010). Evolution of sarcopenia research. Applied Physiology, Nutrition, and Metabolism, 35(5), 707-712. doi: 10.1139/H10-067 VIEW ITEM

Katsanos, C. S. (2006). Prescribing aerobic exercise for the regulation of postprandial lipid metabolism: Current research and recommendations. Sports Medicine, 36(7), 547-560. doi: 10.2165/00007256-200636070-00001 VIEW ITEM

Kay, S. J., \& Fiatarone Singh, M. A. (2006). The influence of physical activity on abdominal fat: a systematic review of the literature. Obesity Reviews , 7(2), 183-200. doi: 10.1111/j.1467-789X.2006.00250.x VIEW ITEM

Keys, A., Taylor, H. L., \& Grande, F. (1973). Basal metabolism and age of adult man. Metabolism, 22(4), 579-587. doi: 10.1016/0026-0495(73)90071-1 VIEW ITEM

Kraus, W. E., Houmard, J. A., Duscha, B. D., Knetzger, K. J., Wharton, M. B., McCartney, J. S., ... Slentz, C. A. (2002). Effects of the Amount and Intensity of Exercise on Plasma Lipoproteins. New England Journal of Medicine, 347(19), 1483-1492. doi: 10.1056/NEJMoa020194 VIEW ITEM

Krems, C., Lührmann, P. M., Straßburg, A., Hartmann, B., \& Neuhäuser-Berthold, M. (2005). Lower resting metabolic rate in the elderly may not be entirely due to changes in body composition. European Journal of Clinical Nutrition, 59(2), 255-262. doi: 10.1038/sj.ejcn.1602066 VIEW ITEM

Kukuljan, S., Nowson, C. A., Sanders, K., \& Daly, R. M. (2009). Effects of resistance exercise and fortified milk on skeletal muscle mass, muscle size, and functional performance in middle-aged and older men: an 18-mo randomized controlled trial. Journal of Applied Physiology, 107(6), 1864-1873. doi: 10.1152/japplphysiol.00392.2009 VIEW ITEM

Lambert, C. P., \& Evans, W. J. (2005). Adaptations to aerobic and resistance exercise in the elderly. Reviews in Endocrine and Metabolic Disorders, 6(2), 137-143. doi: 10.1007/ s11154-005-6726-5 VIEW ITEM

Lanza, I. R., Short, D. K., Short, K. R., Raghavakaimal, S., Basu, R., Joyner, M. J., ... Nair, K. S. (2008). Endurance exercise as a countermeasure for aging. Diabetes, 57(11), 2933-2942. doi: 10.2337/db08-0349 VIEW ITEM

Laukkanen, R., Oja, P., Ojala, K., Pasanen, M., \& Vuori, I. (1992). Feasibility of a 2-km walking test for fitness assessment in a population study. Scandinavian Journal of Social Medicine, 20(2), 119-126. doi: 10.1177/140349489202000210 VIEW ITEM 
Liao, C.-D., Tsauo, J.-Y., Wu, Y.-T., Cheng, C.-P., Chen, H.-C., Huang, Y.-C., ... Liou, T.-H. (2017). Effects of protein supplementation combined with resistance exercise on body composition and physical function in older adults: a systematic review and metaanalysis. The American Journal of Clinical Nutrition, 106(4), 1078-1091. doi: 10.3945/ ajcn.116.143594 VIEW ITEM

Maiorana, A., O'Driscoll, G., Taylor, R., \& Green, D. (2003). Exercise and the nitric oxide vasodilator system. Sports Medicine, 33(14), 1013-1035. doi: 10.2165/00007256200333140-00001 VIEW ITEM

Matsuzawa, Y., Shimomura, I., Nakamura, T., Keno, Y., Kotani, K., \& Tokunaga, K. (1995). Pathophysiology and pathogenesis of visceral fat obesity. Obesity, 3(S2), 187s194s. doi: 10.1002/j.1550-8528.1995.tb00462.x VIEW ITEM

Morley, J. E., Argiles, J. M., Evans, W. J., Bhasin, S., Cella, D., Deutz, N. E. P., ... Anker, S. D. (2010). Nutritional recommendations for the management of sarcopenia. Journal of the American Medical Directors Association, 11(6), 391-396. doi: 10.1016/j. jamda.2010.04.014 VIEW ITEM

Moyer, V. A., on behalf of the U.S. Preventive Services Task Force. (2013). Vitamin D and calcium supplementation to prevent fractures in adults: U.S. Preventive Services Task Force recommendation statement. Annals of Internal Medicine, 158(9), 691-696. doi: 10.7326/0003-4819-158-9-201305070-00603 VIEW ITEM

Muir, S. W., \& Montero-Odasso, M. (2011). Effect of vitamin D supplementation on muscle strength, gait and balance in older adults: a systematic review and meta-analysis. Journal of the American Geriatric Society, 59(12), 2291-2300. doi: 10.1111/j.15325415.2011.03733.x VIEW ITEM

Paniagua, J. A. (2016). Nutrition, insulin resistance and dysfunctional adipose tissue determine the different components of metabolic syndrome. World Journal of Diabetes, 7(19), 483-514. doi: 10.4239/wjd.v7.i19.483 VIEW ITEM

Poehlman, E. T. (1992). Energy expenditure and requirements in aging humans. The Journal of nutrition, 122(11), 2057-2065. VIEW ITEM

Roberts, S. B., \& Rosenberg, I. (2006). Nutrition and aging: Changes in the Regulation of energy metabolism with aging. Physiological Reviews, 86(2), 651-667. doi: 10.1152/ physrev.00019.2005 VIEW ITEM

Rolland, Y., Lauwers-Cances, V., Cristini, C., van Kan, G. A., Janssen, I., Morley, J. E., \& Vellas, B. (2009). Difficulties with physical function associated with obesity, sarcopenia, and sarcopenic-obesity in community-dwelling elderly women: The EPIDOS (EPIDemiologie de l'OSteoporose) Study. American Journal of Clinical Nutrition, 89(6), 1895-1900. doi: 10.3945/ajcn.2008.26950 VIEW ITEM

Romero-Arenas, S., Martínez-Pascual, M., \& Alcaraz, P. E. (2013). Impact of resistance circuit training on neuromuscular, cardiorespiratory and body composition adaptations in the elderly. Aging and Disease, 4(5), 256-263. doi: 10.14336/AD.2013.0400256 VIEW ITEM

Romero-Arenas, S., Blazevich, A. J., Martínez-Pascual, M., Pérez-Gómez, J., Luque, A. J., López-Román, F. J., \& Alcaraz, P. E. (2013). Effects of high-resistance circuit training in an elderly population. Experimental Gerontology, 48(3), 334-340. doi: 10.1016/j.exger.2013.01.007 VIEW ITEM

Rondanelli, M., Klersy, C., Terracol, G., Talluri, J., Maugeri, R., Guido, D., ... Perna, S. (2016). Whey protein, amino acids, and Vitamin D supplementation with physical activity increases fat-free mass and strength, functionality, and quality of life and decreas- 
es inflammation in sarcopenic elderly. American Journal of Clinical Nutrition, 103(3), 830-840. doi: 10.3945/ajcn.115.113357 VIEW ITEM

Sahni, S., Broe, K. E., Tucker, K. L., McLean, R. R., Kiel, D. P., Cupples, L. A., \& Hannan, M. T. (2014). Association of total protein intake with bone mineral density and bone loss in men and women from the Framingham Offspring Study. Public health nutrition, 17(11), 2570-2576. doi: 10.1017/S1368980013002875 VIEW ITEM

Sakuma, K., \& Yamaguchi, A. (2012). Sarcopenia and age-related endocrine function. International Journal of Endocrinology, 2012 art. 127362, 1-10. VIEW ITEM

Sigal, R. J., Kenny, G. P., Boule, N. G., Wells, G. A., Prud'homme, D., Fortier, M., ... Jaffey, J. (2007). Effects of aerobic training, resistance training, or both on glycemic control in type 2 diabetes: a randomized trial. Annals of Internal Medicine, 147(6), 357-369. doi: 10.7326/0003-4819-147-6-200709180-00005 VIEW ITEM

Simpson, K. A., \& Fiatarone Singh, M. A. (2008). Effects of exercise on adiponectin: A systematic review. Obesity, 16(2), 241-256. doi: 10.1038/oby.2007.53 VIEW ITEM

Sonnenberg, G. E., Krakower, G. R., \& Kissebah, A. H. (2004). A novel pathway to the manifestations of metabolic syndrome. Obesity Research, 12(2), 180-186. doi: 10.1038/ oby.2004.24 VIEW ITEM

St-Onge, M. P., \& Gallagher, D. (2010). Body composition changes with aging: The cause or the result of alterations in metabolic rate and macronutrient oxidation? Nutrition, 26(2), 152-155. doi: 10.1016/j.nut.2009.07.004 VIEW ITEM

Strasser, B. (2013). Physical activity in obesity and metabolic syndrome. Annals of the New York Academy of Sciences, 1281(1), 141-159. doi: 10.1111/j.1749-6632.2012.06785.x VIEW ITEM

Strasser, B., Arvandi, M., \& Siebert, U. (2012). Resistance training, visceral obesity and inflammatory response: A review of the evidence. Obesity Reviews, 13(7), 578-591. doi: 10.1111/j.1467-789X.2012.00988.x VIEW ITEM

Swinburn, B. A., Sacks, G., Hall, K. D., McPherson, K., Finegood, D. T., Moodie, M. L., \& Gortmaker, S. L. (2011). The global obesity pandemic: shaped by global drivers and local environments. Lancet (London, England), 378(9793), 804-814. doi: 10.1016/ S0140-6736(11)60813-1 VIEW ITEM

Taylor, A. H., Cable, N. T., Faulkner, G., Hillsdon, M., Narici, M., \& Van der Bij, A. K. (2004). Physical activity and older adults: A review of health benefits and the effectiveness of interventions. Journal of Sports Sciences, 22(8), 703-725. doi: 10.1080/02640410410001712421 VIEW ITEM

Theou, O., Stathokostas, L., Roland, K. P., Jakobi, J. M., Patterson, C., Vandervoort, A. A., \& Jones, G. R. (2011). The effectiveness of exercise interventions for the management of frailty: A systematic review. Journal of Aging Research, 2011 art. 569194, 1-19. doi: 10.4061/2011/569194 VIEW ITEM

Toth, M. J., Beckett, T., \& Poehlman, E. T. (1999). Physical activity and the progressive change in body composition with aging: current evidence and research issues. Medicine and Science in Sports and Exercise, 31(11 Suppl), S590-596. doi: 10.1097/00005768199911001-00017 VIEW ITEM

Tricco, A. C., Thomas, S. M., Veroniki, A. A., Hamid, J. S., Cogo, E., Strifler, L., ... Straus, S. E. (2017). Comparisons of interventions for preventing falls in older adults: A systematic review and meta-analysis. JAMA, 318(17), 1687-1699. doi: 10.1001/ jama.2017.15006 VIEW ITEM 
Villareal, D. T., Aguirre, L., Gurney, A. B., Waters, D. L., Sinacore, D. R., Colombo, E., ... Qualls, C. (2017). Aerobic or Resistance Exercise, or Both, in Dieting Obese Older Adults. New England Journal of Medicine, 376(20), 1943-1955. doi: 10.1056/ NEJMoa1616338 VIEW ITEM

Villareal, D. T., Chode, S., Parimi, N., Sinacore, D. R., Hilton, T., Armamento-Villareal, R., ... Shan, K. (2011). Weight loss, exercise, or both and physical function in obese older adults. New England Journal of Medicine, 364(13), 1218-1229. doi: 10.1056/ NEJMoa1008234 VIEW ITEM

Volaklis, K. A., Douda, H. T., Kokkinos, P. F., \& Tokmakidis, S. P. (2006). Physiological alterations to detraining following prolonged combined strength and aerobic training in cardiac patients. European Journal of Cardiovascular Prevention \& Rehabilitation, 13(3), 375-380. doi: 10.1097/01.hjr.0000198922.42437.39 VIEW ITEM

Whelton, S. P., Chin, A., Xin, X., \& He, J. (2002). Effect of aerobic exercise on blood pressure: A meta-analysis of randomized, controlled trials. Annals of Internal Medicine, 136(7), 493-503. doi: 10.7326/0003-4819-136-7-200204020-00006 VIEW ITEM

Wilson, J. M., Marin, P. J., Rhea, M. R., Wilson, S. M. C., Loenneke, J. P., \& Anderson, J. C. (2012). Concurrent training: a meta-analysis examining interference of aerobic and resistance exercises. Journal of Strength and Conditioning Research, 26(8), 2293-2307. doi: 10.1519/JSC.0b013e31823a3e2d VIEW ITEM

Winnick, J. J., Sherman, W. M., Habash, D. L., Stout, M. B., Failla, M. L., Belury, M. A., \& Schuster, D. P. (2008). Short-term aerobic exercise training in obese humans with type 2 diabetes mellitus improves whole-body insulin sensitivity through gains in peripheral, not hepatic insulin sensitivity. Journal of Clinical Endocrinology and Metabolism, 93(3), 771-778. doi: 10.1210/jc.2007-1524 VIEW ITEM

Witard, O. C., McGlory, C., Hamilton, D. L., \& Phillips, S. M. (2016). Growing older with health and vitality: a nexus of physical activity, exercise and nutrition. Biogerontology, 17(3), 529-546. doi: 10.1007/s10522-016-9637-9 VIEW ITEM

World Health Organization. (2010). Global recommendations on physical activity for health. Retrieved from http://apps.who.int/iris/bitstream/10665/44399/1/9789241599979 eng. pdf

Yang, Y.-R., Wang, R.-Y., Lin, K.-H., Chu, M.-Y., \& Chan, R.-C. (2006). Task-oriented progressive resistance strength training improves muscle strength and functional performance in individuals with stroke. Clinical Rehabilitation, 20(10), 860-870. doi: 10.1177/0269215506070701 VIEW ITEM

Zamboni, M., Mazzali, G., Fantin, F., Rossi, A., \& Di Francesco, V. (2008). Sarcopenic obesity: A new category of obesity in the elderly. Nutrition, Metabolism and Cardiovascular Diseases, 18(5), 388-395. doi: 10.1016/j.numecd.2007.10.002 VIEW ITEM 